\title{
Mitochondrial membrane potential in 2-cell stage embryos correlates with the success of preimplantation development
}

\author{
Kouji Komatsu, Akira Iwase ${ }^{1,2}$, Miki Mawatari ${ }^{3}$, Jingwen Wang ${ }^{3}$, Mamoru Yamashita ${ }^{3}$ and \\ Fumitaka Kikkawa ${ }^{1}$ \\ Bio-database Institute of Reproductive and Developmental Medicine, Nagoya, Japan, ${ }^{1}$ Department of Obstetrics and \\ Gynecology, Nagoya University Graduate School of Medicine, 65 Turumai-cho, Showa-ku, Nagoya 466-8550, Japan, \\ ${ }^{2}$ Department of Maternal and Perinatal Medicine, Nagoya University Hospital, Nagoya, Japan and ${ }^{3}$ Department of \\ Reproduction, Bell Research Center for Reproductive Health and Cancer, Nagoya, Japan
}

Correspondence should be addressed to A Iwase; Email: akiwase@med.nagoya-u.ac.jp

\begin{abstract}
Hormonal stimulation in superovulation induces female mice to ovulate more oocytes than spontaneous ovulation. Because the superovulated oocytes contain a number of oocytes that normally regress before spontaneous ovulation or immature oocytes, the development of some embryos that derive from these oocytes by IVF is prevented. Therefore, the quality of superovulated oocytes should differ from that of spontaneously ovulated oocytes. In this study, we evaluated the quality of superovulated oocytes, by examining 1 - and 2-cell stage embryos, in which the development mainly depends on the maternal mRNA, proteins, and mitochondria that are contained in the oocytes, and we then measured the mitochondrial membrane potential $\left(\Delta \Psi_{m}\right)$ of the 1- and 2-cell stage, in vivo-fertilized, and IVF embryos. The $\Delta \Psi_{m}$ of 1-cell stage IVF embryos was lower than that of in vivo-fertilized embryos; however, there was no difference between IVF embryos. During the developmental process from 1- to 2-cell stage, the $\Delta \Psi_{m}$ of in vivo-fertilized embryos was highly upregulated, whereas a number of IVF embryos remained unchanged. As a result, 2-cell stage embryos were divided into two groups: high- and low- $\Delta \Psi_{m}$ 2-cell stage IVF embryos. The development of low- $\Delta \Psi_{m}$ 2-cell stage IVF embryos tended to be arrested after the 2-cell stage. These results indicated that the upregulation of $\Delta \Psi_{m}$ during the 1- to 2-cell stage was important in the development of early preimplantation embryos; there were some defects in the mitochondria of superovulated oocytes, which prevented their development. Reproduction (2014) $\mathbf{1 4 7} 627-638$
\end{abstract}

\section{Introduction}

The quality of an oocyte influences the maturation, fertilization, and development of embryos; however, the factors that determine oocyte quality are not yet clear (Mermillod et al. 2008). After fertilization, maternal mRNA and proteins in the fertilized oocyte are gradually degraded, and the minor transcriptional wave of zygotic gene activation (ZGA) is simultaneously initiated (Tsukamoto et al. 2008, Tadros \& Lipshitz 2009). Oocyte quality affects development after the 2-cell stage because some maternal mRNA is stable after ZGA (Hamatani et al. 2004, Tadros \& Lipshitz 2009). Thus, these maternal factors are critical for early preimplantation development and determine oocyte quality.

More oocytes are ovulated by hormonal stimulation than by spontaneous ovulation. These superovulated oocytes are generally considered to contain some oocytes that would normally be degraded before spontaneous ovulation or that are still immature during ovulation so that some oocytes may not store enough maternal mRNA and proteins. Hormonal stimulation for superovulation influences maternal mRNA gene expression (Mundim et al. 2009). In addition to maternal mRNA and proteins, mitochondria are inherited to oocytes as the maternal factor (Sato \& Sato 2011). Approximately 100000 mitochondria are contained in the mature oocytes of humans and mice (Piko \& Taylor 1987, Reynier et al. 2001, Wai et al. 2010). In contrast, there are very few or no paternal mitochondria in fertilized oocytes and embryonic cells (Lansman et al. 1983, Gyllensten et al. 1991) because few mitochondria are contained in sperm and paternal mitochondria are selectively destroyed by the ubiquitin system in fertilized oocytes (Sutovsky et al. 1999, 2000). Therefore, maternal mitochondria play a major role in energetic conversions and calcium homeostasis, and the quality of maternal mitochondria in oocytes is crucial for embryonic development.

Mitochondrial morphology and localization are markedly changed during oocyte maturation and 
preimplantation development (Motta et al. 2000). The mitochondria in oocytes proliferate during follicular development; however, they contain very few cristae at this stage (Wai et al. 2010). After fertilization, mitochondria dramatically change in size and shape (Wai et al. 2008, 2010). In oocytes at the early-prophase stage, mitochondria localize along the outer surface of the nuclear membrane. During follicular development, mitochondria proliferate and disperse in the ooplasm. In ovulated oocytes, mitochondria aggregate around the smooth endoplasmic reticulum. In the pronuclear zygote, mitochondria concentrate around the pronuclei (Motta et al. 2000). In the process of changing their location, highly polarized mitochondria (with high membrane potential $\left.\left(\Delta \Psi_{\mathrm{m}}\right)\right)$ are localized in the subplasmalemmal cytoplasm (Van Blerkom et al. 2002, Van Blerkom \& Davis 2006). This localization is observed from the germinal vesicle-stage oocytes to the 4-cell stage embryos. It is unclear why highly polarized mitochondria are localized in this site; however, mitochondrial activity (high $\Delta \Psi_{\mathrm{m}}$ ) is important for human preimplantation embryo development because a significant loss in the subplasmalemmal domains of mitochondria with high $\Delta \Psi_{\mathrm{m}}$ induces the arrest of cell division (Wilding et al. 2001).

According to the changes in mitochondrial morphology and localization, the ATP production of mitochondria is activated. The $\Delta \Psi_{\mathrm{m}}$ is indispensable for ATP production and is mainly controlled by the transportation of $\mathrm{H}^{+}$ions (Wilding et al. 2009, Drago et al. 2011). $\mathrm{H}^{+}$ions are transported from the matrix to the intermembrane space by oxidative phosphorylation (OXPHOS) complexes. Complex I (NADH: ubiquinone oxidoreductase) is the entry point for the electrons from $\mathrm{NADH}+\mathrm{H}^{+}$into the respiratory chain (Hirst et al. 2003, Sazanov 2007). The energy is released as two electrons from $\mathrm{NADH}+\mathrm{H}^{+}$are used to transport $\mathrm{H}^{+}$ions from the mitochondrial matrix to the intermembrane space. In addition to $\mathrm{NADH}+\mathrm{H}^{+}$, the electrons are transferred from flavin adenine dinucleotide and succinated by complex II (succinate dehydrogenase (SDH)) into the respiratory chain. These electrons convert ubiquinone (coenzyme $\mathrm{Q}_{10}(\mathrm{CoQ})$ ) to ubiquinol $\left(\mathrm{CoQH}_{2}\right)$ and are successively transferred from $\mathrm{CoQH}_{2}$ to complex III. After the transfer to complex III, the electrons are transferred to cytochrome $c$, complex IV, and finally to molecular oxygen $\left(\mathrm{O}_{2}\right)$ to provide $\mathrm{H}_{2} \mathrm{O}$. During this process, the energy derived from the electronic flow at complex III and complex IV is used to transport $\mathrm{H}^{+}$ions into the intermembrane space. Thus, $\Delta \Psi_{\mathrm{m}}$ is formed by $\mathrm{H}^{+}$ions transported through complexes I, III, and IV, and the stored energy of the $\Delta \Psi_{\mathrm{m}}$ is used to produce ATP with complex $\mathrm{V}$ for generating heat and importing $\mathrm{Ca}^{2+}$ into the mitochondria (Wallace \& Fan 2010). When correlated with the activation of the mitochondria, the production of reactive oxygen species (ROS) is increased through the respiratory chain process. The ROS sources are mainly complexes I and III; the superoxide anion $\left(\mathrm{O}_{2}^{-}\right)$produced at complex $\mathrm{I}$ is released into the matrix of the mitochondria (Turrens 2003). In contrast, $\mathrm{O}_{2}^{-}$ produced at complex III is released into the matrix and the intermembrane space of mitochondria, and most of the ROS generated by complex III are released into the intermembrane space (St-Pierre et al. 2002, Brand 2010). $\mathrm{O}_{2}^{-}$is a precursor of most other ROS, and it is enzymatically converted to $\mathrm{H}_{2} \mathrm{O}_{2}$ by a family of metalloenzymes called superoxide dismutases (SOD); SOD1 (Cu, Zn-SOD) localizes in the intermembrane space and the cytosol, SOD2 (Mn-SOD) localizes in the matrix, and SOD3 localizes in the extracellular fluids and spaces (St-Pierre et al. 2002, Fattman et al. 2003, Turrens 2003, Combelles et al. 2010). Embryos that were derived from SOD1-deficient mice oocytes were arrested at the 2-cell stage in culture under atmospheric oxygen conditions; however, they were able to avoid 2-cell arrest by incubation under hypoxic conditions (Kimura et al. 2010). Furthermore, SOD1-deficient embryos that avoided 2-cell arrest underwent degeneration after the 4-cell stage by oxidative stress under atmospheric oxygen conditions (Kimura et al. 2010).

Thus, the $\Delta \Psi_{\mathrm{m}}$ is closely associated with the production of ROS, and ROS affects the development of preimplantation embryos. In order to evaluate the quality of superovulated oocytes, it is important to estimate the $\Delta \Psi_{\mathrm{m}}$ and volume of ROS in embryos. In this experiment, we measured the $\Delta \Psi_{\mathrm{m}}$ and ROS of 1and 2-cell stage in vivo-fertilized and IVF embryos with fluorescence probes and investigated whether they affected the preimplantation development of the embryos.

\section{Materials and methods}

\section{Collection of embryos and culture}

Embryos were obtained from female ICR mice (age, 8-10 weeks; Japan SLC, Inc., Shizuoka, Japan). Female mice were caged overnight with a male ICR mouse (Japan SLC, Inc.) for mating, and the copulatory plug of the mated female mice was checked the following morning. One-cell stage embryos were obtained from the oviducts of mated female mice in the evening, and the 2-cell stage embryos were obtained the following morning. All mice were housed in an environmentally controlled room at $23 \pm 1{ }^{\circ} \mathrm{C}$ with a $12 \mathrm{~h}$ light: $12 \mathrm{~h}$ darkness cycle photoperiod. The animal care and experiments were conducted in accordance with the Guidelines of Animal Experimentation of the Bio-database Institute of Reproductive and Developmental Medicine, which is based on the guidelines published by the Science Council of Japan.

\section{IVF and embryo culture}

Sperm were collected from 10- to 15 -week-old male ICR mice (Japan SLC, Inc.). The cauda epididymis were dissected, and a small slit was made in the cauda in order to obtain the sperm, 
which were cultured for $2 \mathrm{~h}$ in $100 \mu \mathrm{l}$ of Fertiup medium (Kyudo Co., Ltd, Saga, Japan) in $5 \% \mathrm{CO}_{2}$ in air at $37^{\circ} \mathrm{C}$.

Oocytes were obtained from female ICR mice (age, 9-10 weeks) that were superovulated by i.p. injections of $7.5 \mathrm{U}$ of pregnant mare serum gonadotropin (ASKA Pharmaceutical. Co., Ltd, Tokyo, Japan), which was followed by i.p. injections of $6 U$ of human chorionic gonadotropin (ASKA Pharmaceutical. Co., Ltd, Kumamoto, Japan) after 48 h. At 14-15 h after the human chorionic gonadotropin injection, oocyte-cumulus complexes were obtained from oviducts and transferred into $200 \mu$ l of human tubal fluid medium (ARK Resource Co., Ltd, Kumamoto, Japan). Pre-cultured sperms were injected into the medium containing oocytes. Sperm concentration was controlled to $150 \mathrm{sperm} / \mu \mathrm{l}$. Six hours after gamates co-incubation, the oocytes were transferred into mWM culture medium (ARK Resource Co., Ltd). The oocytes were washed in mWM, and fertilized oocytes that contained a second polar body, a male pronucleus, and a female pronucleus were selected (LachamKaplan \& Trounson 2008). Fertilized oocytes were cultured up to the 2-cell or the blastocyst stage in $5 \% \mathrm{CO}_{2}$ in air at $37^{\circ} \mathrm{C}$. The medium was dropped onto a $3.5-\mathrm{cm}$ culture dish and covered with liquid paraffin (Wako Pure Chemical Industries, Ltd, Osaka, Japan).

\section{Quantification of $\Delta \Psi_{m}, R O S$, and lipid peroxidation- derived protein modification in the blastomere}

The 1- and 2-cell stage embryos that were derived from natural mating and those that were derived from IVF were each separated into two groups. Some embryos within each of the two groups, natural mating and IVF, were used to measure the $\Delta \Psi_{\mathrm{m}}$, ROS, and lipid peroxidation-derived protein modification in the blastomeres, and the other embryos were cultured for 5 days in order to check the rate of blastocyst formation.

The 1- and 2-cell stage embryos were incubated in mWM

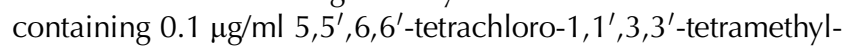
benzimidazol carbocyanine iodide (JC-1, Life Technologies Corporation), $1.25 \mu \mathrm{M}$ CellRox Deep Red Reagent (Life Technologies Corporation), and $50 \mu \mathrm{M}$ linoleamide alkyne (LAA, catalog no. 10446, Life Technologies Corporation) in $5 \% \mathrm{CO}_{2}$ in air at $37{ }^{\circ} \mathrm{C}$ for $30 \mathrm{~min}$. After incubation, the embryos were washed twice with mWM. Stained embryos were transferred to $20 \mu \mathrm{l}$ of $\mathrm{mWM}$ and covered with liquid paraffin in a 3.5-cm glass bottom dish (MatTek Corporation, Ashland, MA, USA), and images were captured with a confocal microscope (FV1000, Olympus Corporation, Tokyo, Japan). The Z-step size was $3 \mu \mathrm{m}$ and the Z-stack thickness was around $\sim 60 \mu \mathrm{m}$.

JC- 1 is normally a monomer in the cell; it enters mitochondria in proportion to the membrane potential and forms J-aggregates at high intramitochondrial concentrations that are induced by higher $\Delta \Psi_{\mathrm{m}}$ values. The excitation/ emission wavelengths were $514 / 529 \mathrm{~nm}$ for the monomer and $585 / 590 \mathrm{~nm}$ for the J-aggregate (Smiley et al. 1991). The CellRox Deep Red Reagent specifically detects ROS in the cells, and the emission/excitation wavelength was 640/ $665 \mathrm{~nm}$. The ratio of the values of 529:590 nm of JC-1 indicates the $\Delta \Psi_{\mathrm{m}}$ (Mancini et al. 1997, Wadia et al. 1998). The fluorescence signal intensity in the blastomeres was measured with ImageJ (http://rsbweb.nih.gov/ij/). The outline of the blastomeres in the image was traced with a tablet pen (Intuos, Wacom Company, Ltd, Saitama, Japan), and the number of pixels in the blastomeres and the JC-1 and ROS signal intensities were measured. The sum of measured values of each Z-step image was regarded as the total number of pixels and the signal intensity in the whole blastomere. Because the cell volume differed and was dependent on the blastomeres, the signal intensity per one pixel was calculated in order to compare the level of the $\Delta \Psi_{\mathrm{m}}$ and ROS of each blastomere.

After capturing the JC-1 and ROS images, embryos were fixed in 4\% paraformaldehyde (Nacalai Tesque, Inc., Kyoto, Japan) at $4{ }^{\circ} \mathrm{C}$ overnight. Following three washes with Dulbecco's PBS containing no calcium and no magnesium (PBS(-), Nissui Pharmaceutical Company, Ltd, Tokyo, Japan), embryos were blocked with $1 \%$ BSA/PBS $(-)$ for 20 min at room temperature and incubated with the reaction cocktail for $30 \mathrm{~min}$ at room temperature. After the reaction, the embryos were washed twice with $1 \% \mathrm{BSA} / \mathrm{PBS}(-)$ and twice with $\operatorname{PBS}(-)$. Following the wash, the embryos were transferred to $20 \mu \mathrm{l}$ of $\mathrm{PBS}(-)$ and were covered with liquid paraffin in a 3.5-cm glass bottom dish (MatTek Corporation), and images were captured with a confocal microscope (FV1000, Olympus Corporation). The Z-step size was $3 \mu \mathrm{m}$, and the Z-stack thickness was $\sim 60 \mu \mathrm{m}$. All procedures for LAA detection were conducted according to the protocol of the Click-iT Lipid Peroxidation Detection with LAA (catalog no. 10446, Life Technologies Corporation). The measurement process and the LAA signal intensity calculation were the same as that specified for JC-1 and ROS.

\section{Tracing embryo development}

The embryonic developmental process from the 2-cell stage to blastocyst was captured with a confocal scanner box CellVoyger (CV1000, Yokogawa Electric Coporation, Tokyo, Japan). Two-cell stage embryos were added to $40 \mu \mathrm{l}$ of $\mathrm{mWM}$ in a $3.5 \mathrm{~cm}$ glass bottom dish and covered with liquid paraffin (Wako Pure Chemical Industries, Ltd). Images were captured at 10 -min intervals in $5 \% \mathrm{CO}_{2}$ at $37{ }^{\circ} \mathrm{C}$. In order to trace the developmental process, some embryos were sequentially observed with the CV1000, whereas others were observed every $12 \mathrm{~h}$ with a stereo microscope (SZ61, Leica Microsystems GmbH, Wetzlar, Germany).

Embryos were classified into the following three groups: group 1 , the blastocyst formation rate was $\geq 80 \%$ in IVF embryos (hereafter shown as $\geq 80 \%$ IVF embryos); group 2, the rate was $<80 \%$ in IVF embryos (hereafter shown as $<80 \%$ IVF embryos); and group 3, embryos were obtained from natural mating females (hereafter shown as in vivo-fertilized embryos). The mWM that was used in these experiments guaranteed $>80 \%$ blastocyst formation by the supplier (ARK Resource Co. Ltd; the result of quality control testing is freely available on the web, http://www.ark-resource.co.jp/), and therefore groups 1 and 2 were separated on the basis of the blastocyst formation rate.

\section{Western blotting}

In order to determine the levels of expression of OXPHOSrelated complexes in mitochondria and SOD1 and 2, protein 
lysates were extracted from $\sim 1002$-cell stage embryos that were derived from each of the groups with $5 \mu$ l of lysis buffer (PRO-PREP Protein Extraction Solution, iNtRON Biotechnoligy, Inc., Seoul, Korea). In order to evaluate the levels of expression, glyceraldehyde-3-phosphate dehydrogenase $(\mathrm{GAPDH})$ and $\boldsymbol{\alpha}$-tubulin were detected as internal standards. The voltage-dependent anion channel 1 (VDAC1) was detected as a mitochondria marker for comparison. The lysates were mixed with $5 \times$ sample loading buffer $(62.5 \mathrm{mM}$ Tris- $\mathrm{HCl}(\mathrm{pH}$ 6.8; Nacalai Tesque, Inc.), 10\% glycerol, 5\% mercaptoethanol, $2.5 \%$ SDS, and $0.05 \%$ bromophenol blue (Kanto Chemical Co., Inc., Tokyo, Japan)) and boiled at $95{ }^{\circ} \mathrm{C}$ for $5 \mathrm{~min}$. The boiled lysates were loaded into 5-20\%-gradient acrylamide gel (Atto Co., Ltd, Tokyo, Japan) and transferred onto polyvinylidene difluoride membranes (GE Healthcare UK Ltd, Little Chalfont, Bucks, UK). The lysates that were used to detect the complexes of OXPHOS were not boiled, as per the instructions in the datasheet. The membrane was blocked with BlockingOne (Nacalai Tesque, Inc.) overnight at $4{ }^{\circ} \mathrm{C}$ and reacted with the following primary antibodies: a monoclonal OXPHOS Rodent WB antibody Cocktail (1:500 dilution, Abcam plc, Cambridge, UK), an anti-SOD1 antibody (1:500 dilution, Enzo Life Sciences, Inc., Farmingdale, NY, USA), or an anti-GAPDH antibody (1:500 dilution, Cell Signaling Technology, Inc., Danvers, MA, USA) for $1 \mathrm{~h}$ at room temperature. After three washes in TBST (Tris(hydroxymethyl)aminomethane, Nacalai Tesque, Inc.; $\mathrm{NaCl}$, Nacalai Tesque, Inc.; HCl, Nacalai Tesque, Inc.; Tween20 (0.05\%), Kanto Chemical Co., Inc.), the membrane was reacted with secondary antibodies that were conjugated with horseradish peroxidase (HRP), including a goat anti-mouse antibody (OXPHOS, 1:1000 dilution, GE
Healthcare UK Ltd) or a goat anti-rabbit antibody (SOD1 and GAPDH, 1:1000 dilution, GE Healthcare UK Ltd) for $1 \mathrm{~h}$ at room temperature. The membrane was washed three times with TBST and then incubated for 1 min with ECL Plus Western Blotting Detection Kit (GE Healthcare UK Ltd). After capturing the image with LAS4000 (GE Healthcare UK Ltd), the membrane was treated with ReBlot Plus Mild Solution (Merck Chemicals $\mathrm{GmbH}$ ) for $15 \mathrm{~min}$ at room temperature, and the same procedure as that used for OXPHOS, SOD1, and GAPDH was performed in order to detect $\boldsymbol{\alpha}$-tubulin, SOD2, and VDAC1. Primary antibodies, including the anti- $\alpha$-tubulin antibody (1:1000 dilution, Cell Signaling Technology, Inc.), the anti-SOD2 antibody (1:500 dilution, R\&D Systems, Inc., Minneapolis, MN, USA), and the anti-VDAC1 antibody (1:500, Abcam plc) were used. Secondary antibodies, including the goat anti-rabbit antibody ( $\alpha$-tubulin and VDAC1, 1:1000 dilution) and the goat anti-mouse antibody (SOD2, 1:1000 dilution), were used. The intensity of each captured signal was measured by ImageJ. The intensities of complexes I and III, SOD1, and VDAC1 were normalized to that of $\alpha$-tubulin.

\section{ATP measurement}

The concentration of ATP in the 2-cell stage embryos was measured by a tissue ATP measurement kit (TOYO B-Net Co., Ltd, Tokyo, Japan). Twenty to 50 2-cell stage embryos were homogenized with $100 \mu \mathrm{l}$ of distilled deionized water and $100 \mu \mathrm{l}$ of ATP extraction buffer was added. Following $30 \mathrm{~min}$ of incubation at room temperature, $200 \mu \mathrm{l}$ of luminescence buffer was added and mixed. The total reacted solution was divided into two aliquots of $200 \mu \mathrm{l}$ and applied into two wells of a
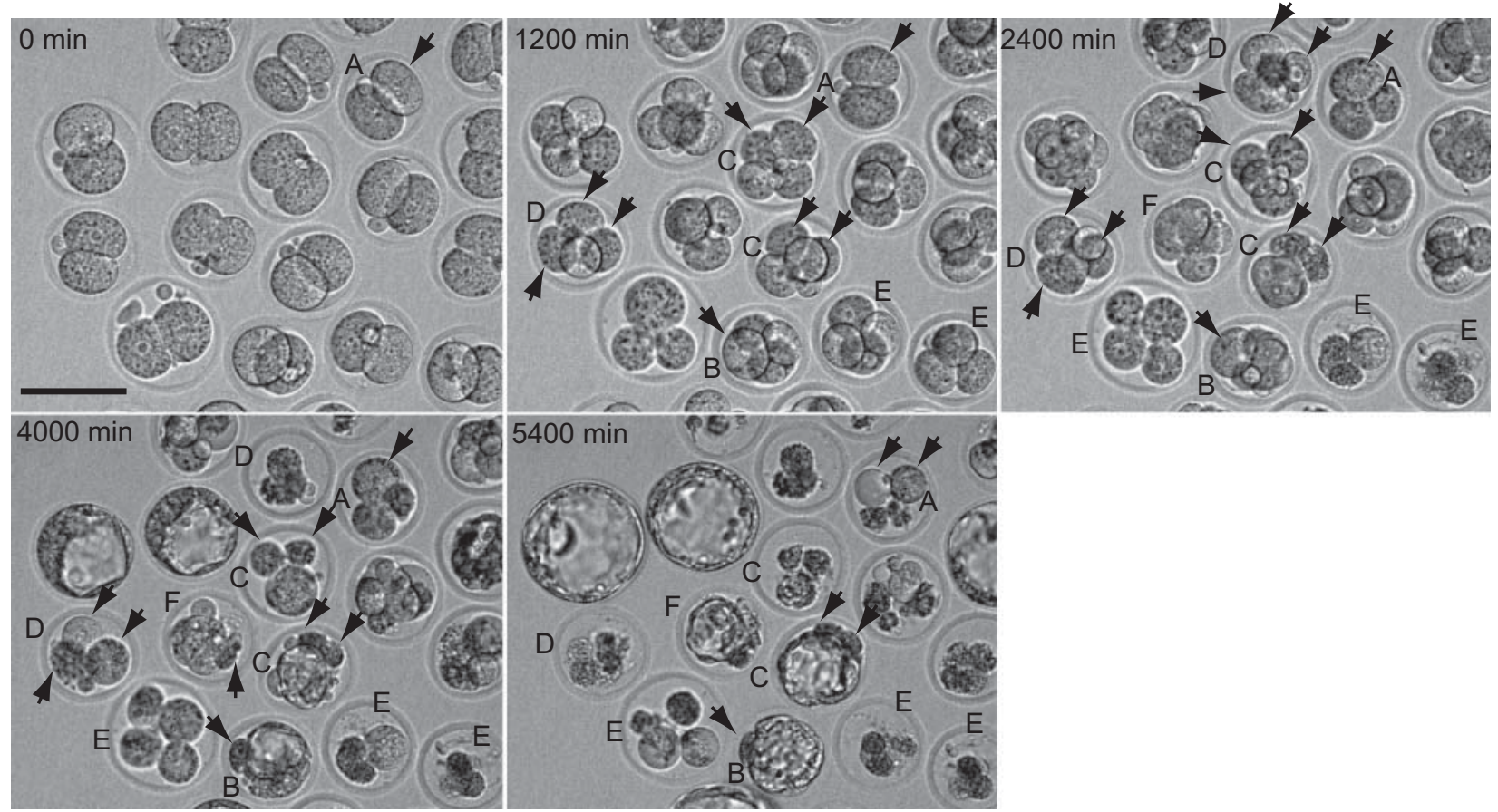

Figure 1 Time-lapse imaging of IVF embryos. Time-lapse imaging of embryos contained in group 19 (Table 1) at 0, 1200, 2400, 4000, and 5400 min. A, B, C, D, E, and F indicate the disturbances in the developmental pattern. The arrows indicate the arrested blastomeres in the embryos. The scale bar indicates $100 \mu \mathrm{m}$. 
96-well plate. The signal intensity of each sample was measured with ARVO X4 (Perkin Elmer, Inc., Waltham, MA, USA), and the mean of the two measured values was considered as the concentration of ATP in the sample.

\section{Statistical analyses}

Statistical analyses were performed with the software R (http:// www.r-project.org/). The normality of all data, including the measurement values of JC-1, ROS, LAA, western blotting, and ATP, was evaluated by a Shapiro-Wilk normality test $(P>0.05)$. As a result, the measurement values of the ROS indicated a normal distribution, but those of JC-1, LAA, western blotting, and ATP indicated non-normal distributions. Therefore, we analyzed the measurement values by a Student's $t$-test for ROS, Mann-Whitney $U$ tests for JC-1 and LAA, and Kruskal-Wallis rank sum tests for the western blotting and ATP. We compared the measurement values between each sample, IVF and IVF embryos, 1 - and 2-cell stage embryos, and $\geq 80$ and $<80 \%$
IVF embryos. Some of IVF embryos were cultured for 5 days, and we counted the number of blastocyst to check the rate of blastocyst formation. According to the results, we distinguished embryos into $\geq 80$ and $<80 \%$ IVF embryos. The number of blastomeres in which the signal intensity of JC-1, ROS, and LAA was measured is indicated in the relevant figures. We conducted each experiment, the western blotting and the ATP measurement, three times. The data are expressed as the mean \pm s.E.M., unless stated otherwise.

\section{Results}

\section{Blastocyst formation rate of in vivo-fertilized and IVF embryos}

The results of the development after a 5-day culture are indicated in Table 1. Embryos that were derived from female nos 13, 14, and 16-19 were sequentially monitored with time-lapse imaging. The other groups
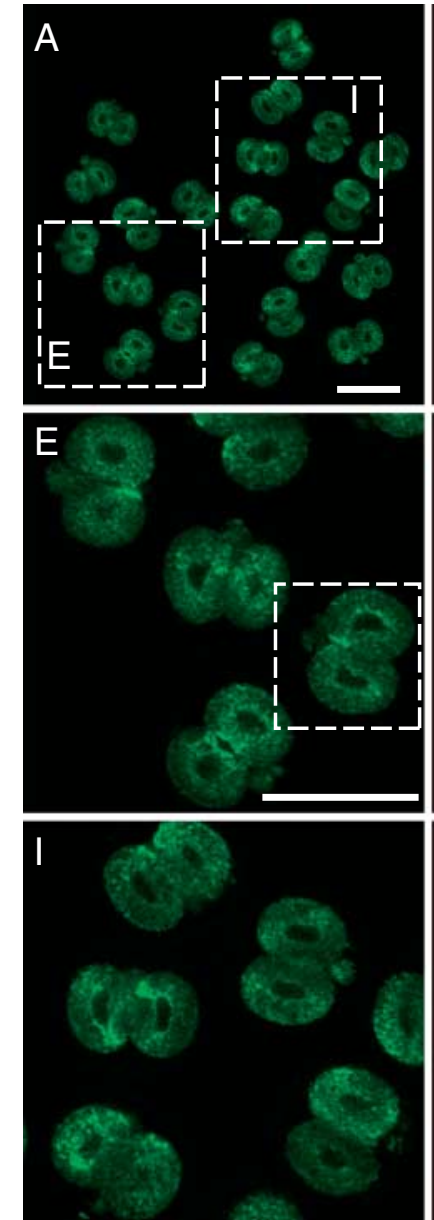
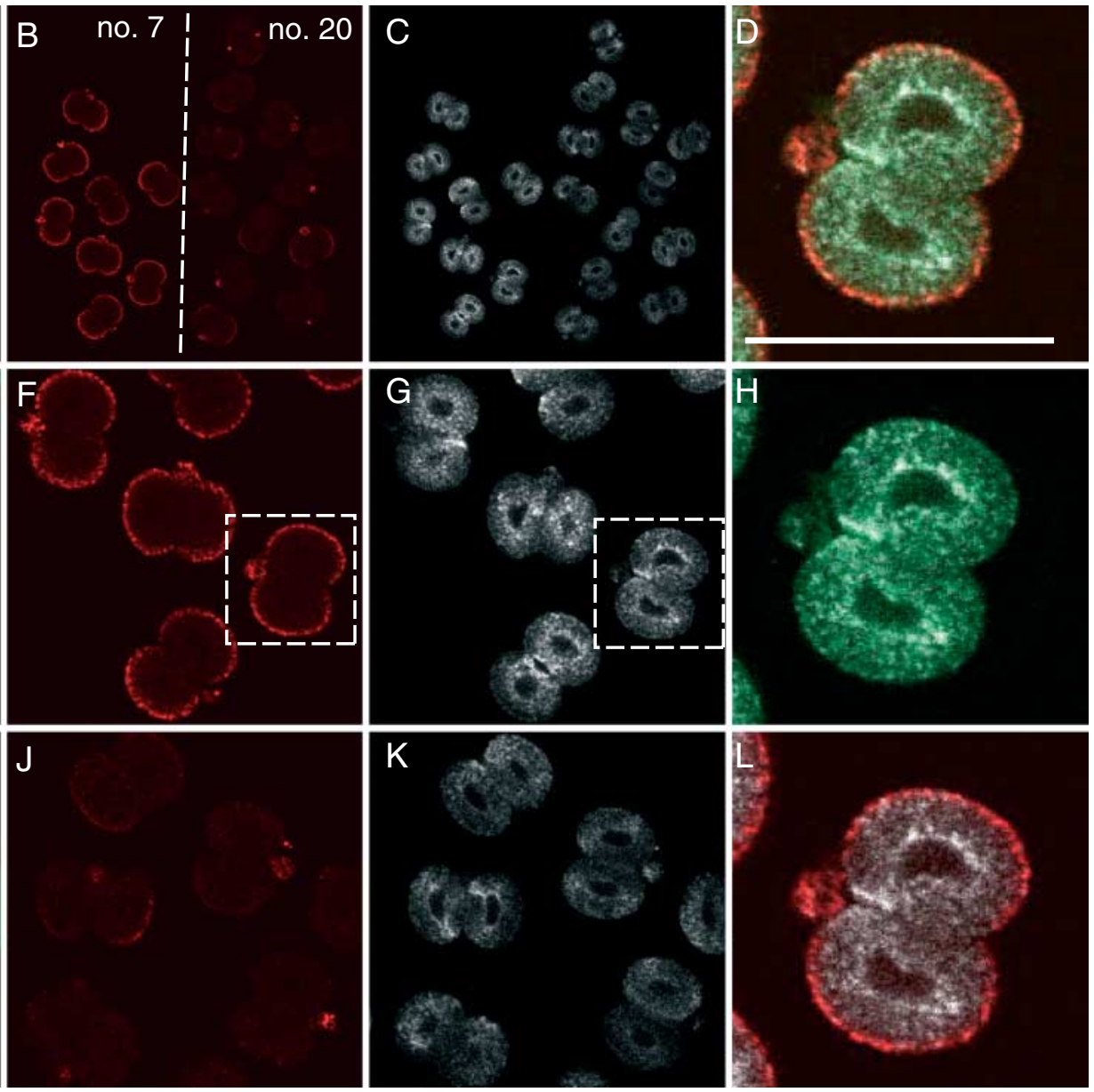

Figure 2 The mitochondrial membrane potential $\left(\Delta \Psi_{m}\right)$ and reactive oxygen species (ROS) in the 2-cell stage embryos. The numbers in panel $B$, no. 7 and no. 20, correspond to the female numbers in Table 1. Panels E, F, and G indicate embryos in the broken line square E in panel A. Panels I, J, and $\mathrm{K}$ indicate embryos in the broken line square $\mathrm{I}$ in panel $\mathrm{A}$. The image in panel $\mathrm{D}$ is merged with panels $\mathrm{E}, \mathrm{F}$, and $\mathrm{G}$. The image of panel $\mathrm{H}$ is merged with panels $E$ and $G$. The image of panel $L$ is merged with panels $F$ and $G$. Panels $A, E$, and I: 5, $5^{\prime}, 6,6^{\prime}$-tetrachloro- $1,1^{\prime}, 3,3^{\prime}$-tetramethylbenzimidazol carbocyanine iodide (JC-1; $529 \mathrm{~nm})$. Panels B, F, and J: JC-1 (590 nm); and panels C, G, and K: ROS (665 nm). The scale bar indicates $100 \mu \mathrm{m}$. 

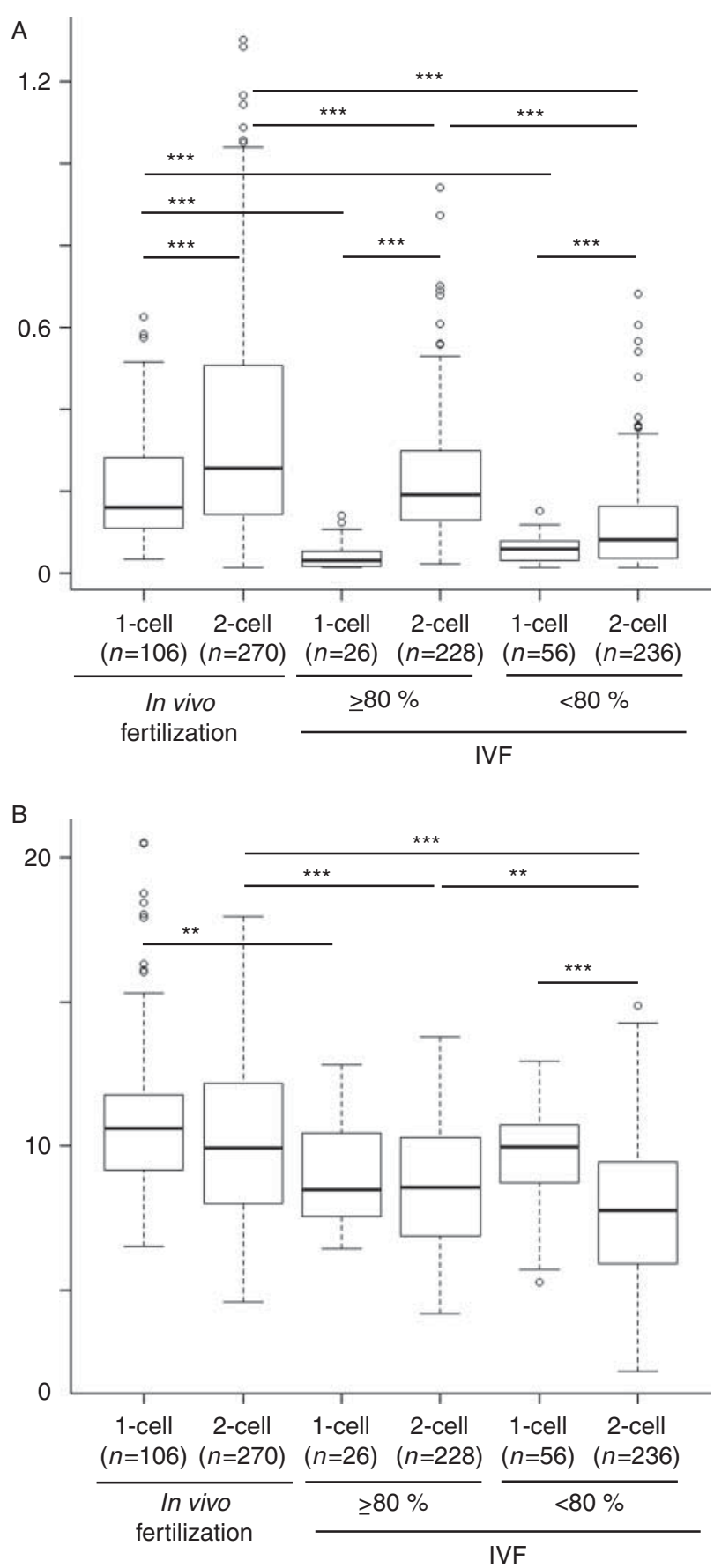

Figure 3 The mitochondrial membrane potential $\left(\Delta \Psi_{\mathrm{m}}\right)$ and reactive oxygen species (ROS) of blastomeres in 1- and 2-cell stage embryos. The box plots indicate the measured values of $\Delta \Psi_{\mathrm{m}}(\mathrm{A})$ and ROS (B) in the blastomeres of embryos in each group, $\geq 80 \%$ IVF embryos, $<80 \%$ IVF embryos, 2-cell stage in vivo-fertilized embryos, and 1-cell stage in vivo-fertilized embryos. The line in the box indicates the median. $\mathrm{n}$ indicates the number of blastomeres measured. Mean \pm s.D., $* * P<0.01,{ }^{* * *} P<0.001$.

were observed at 12-h intervals for 5 days. Some IVF embryos had a low blastocyst formation rate $(<50 \%$ : female nos 16-20, Table 1). Two-cell stage in vivofertilized embryos were obtained from the oviduct of five female mice and cultured. All these embryos formed blastocysts (100\%, 25/25).

The extracted time-lapse images of IVF embryos derived from female no. 19 (Table 1) are shown in Fig. 1. In these embryos, seven embryos formed blastocysts (23.3\%; 7/30, Table 1) and the development of the others was arrested before blastocyst formation (23/30, Table 1). Time-lapse imaging analysis indicated that cell cleavage was arrested between the 2 - and 4-cell stages in almost all the embryos (21/23, Table 2). There were six different types of cell cleavage arrest. Type A consisted of the development of one blastomere that was arrested at the 2-cell stage and another blastomere that was cleaved (1/23; Fig. 1 A and Table 2). Type B consisted of the development of one blastomere that was arrested at the 4-cell stage and three other blastomeres that were cleaved (5/23; Fig. 1B and Table 2). Type C consisted of the development of two blastomeres that were derived from the same blastomere at the 2-cell stage and that were arrested at the 4-cell stage and other blastomeres that were cleaved (4/23; Fig. 1C and Table 2). Type D consisted of the development of three blastomeres that were arrested at the 4-cell stage and the remaining blastomere that was cleaved (2/23; Fig. 1D and Table 2). Type $E$ consisted of the development of all four blastomeres that were arrested at the 4-cell stage (9/23; Fig. 1E and Table 2). Finally, type $\mathrm{F}$ consisted of the development of some blastomeres after the 4-cell stage that were arrested and the remaining blastomeres that were cleaved (2/23; Fig. 1F and Table 2). Seventy-seven embryos (from a total of 135 embryos) in female numbers 13, 14, and 16-19 (Table 1), which were observed with time-lapse imaging, exhibited disturbed blastocyst formation and 56 embryos out of 77 were arrested at the cleavage of the blastomere between the 2and 4-cell stage (Table 2). This result indicated that some defect prevented the development of some IVF embryos between 2- and 4-cell stage.

\section{Measurement of $\Delta \Psi_{m}, R O S$, and lipid peroxidation- derived protein modification in the blastomeres of the 1- and 2-cell stage}

In order to compare $\Delta \Psi_{\mathrm{m}}$ and ROS in the blastomeres of in vivo-fertilized and IVF embryos, the 1 - and 2 -cell stage embryos of each group were stained with the fluorescent probes, JC-1, and CellROX DeepRed reagent (Fig. 2). JC-1 localizes in mitochondria; therefore, the JC-1 signal indicates the level of $\Delta \Psi_{\mathrm{m}}$ and the localization of mitochondria in embryos. At the 2-cell stage, the JC-1 green signal $(529 \mathrm{~nm})$, which indicates low $\Delta \Psi_{\mathrm{m}}$, was observed around the cell nucleus and in the cytoplasm (Fig. 2A). The red signal of JC-1 $(590 \mathrm{~nm})$, which indicates high $\Delta \Psi_{\mathrm{m}}$, aggregated in the subplasmalemmal cytoplasm, and a small red dot signal was also observed in the cytoplasm (Fig. 2B). These results indicated that mitochondria with high $\Delta \Psi_{\mathrm{m}}$ mainly 

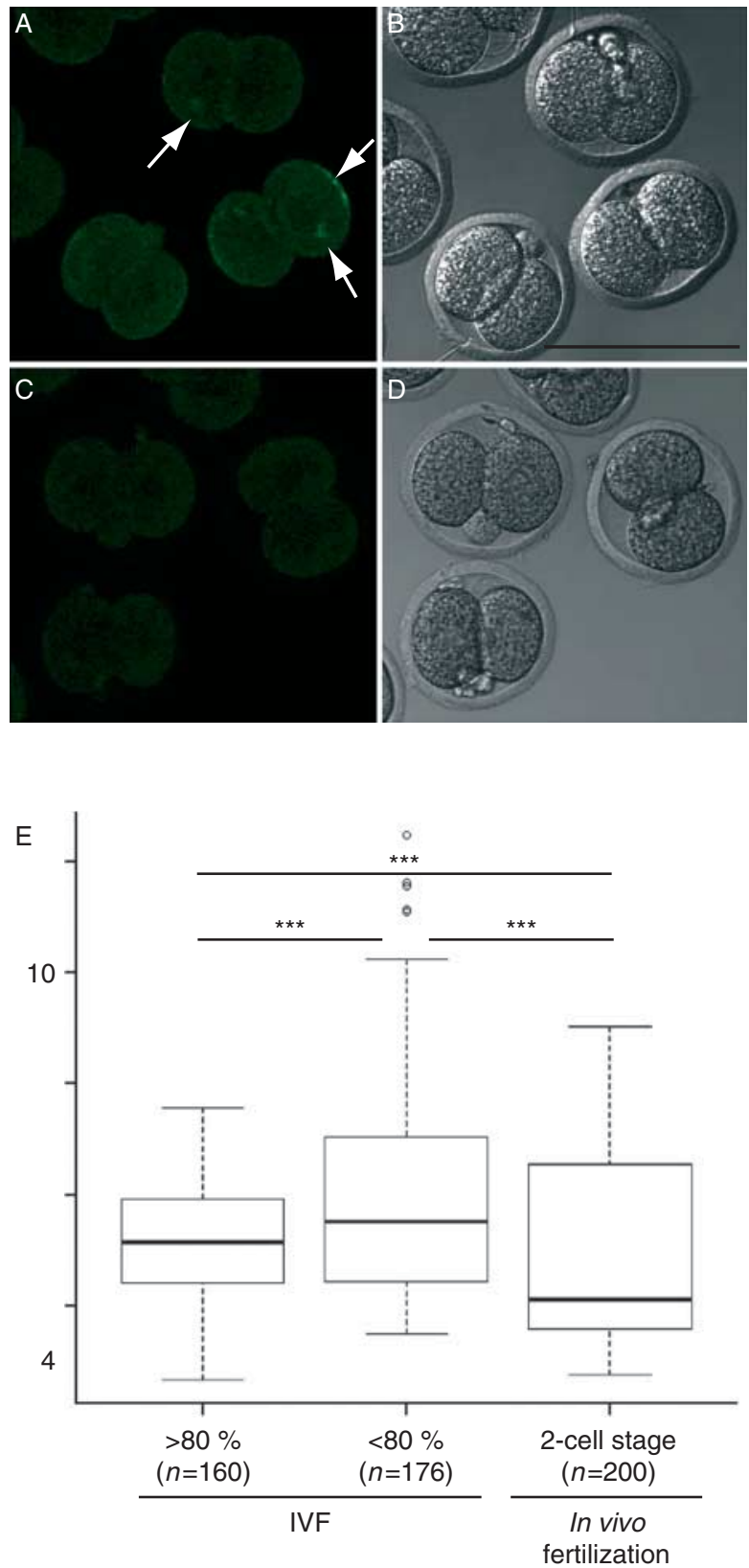

Figure 4 Protein modification by lipid peroxidation in the 2-cell stage embryos. The signals in $\mathrm{A}$ and $\mathrm{C}$ denote the lipid peroxidation-derived protein modification in the 2-cell stage embryos. $\mathrm{B}$ and $\mathrm{D}$ are brightfield images of $\mathrm{A}$ and $\mathrm{C}$. (A and $\mathrm{B})<80 \%$ IVF embryos. (C and D) $\geq 80 \%$ IVF embryos. (E) The box plot illustrates the signal intensity of each group of embryos. Mean \pm s.D., ${ }^{* * *} P<0.001$. The scale bar indicates $100 \mu \mathrm{m}$. The arrows indicate the localization of modified proteins.

localized in the subplasmalemmal cytoplasm and that mitochondria with low $\Delta \Psi_{\mathrm{m}}$ localized in the cytoplasm. The ROS signals were mainly co-localized with the JC-1 signal (Fig. 2C and D). Strong ROS signals were localized in the mitochondria with low $\Delta \Psi_{\mathrm{m}}$, whereas mitochondria with high $\Delta \Psi_{\mathrm{m}}$ contained low ROS levels (Fig. 2E, F, G, and H).
The total pixels in the whole blastomere and the intensities of the JC- 1 and ROS signals were measured with Image), and the intensity of each signal per one pixel was compared among all the groups (Fig. 3). These results revealed that the $\Delta \Psi_{\mathrm{m}}$ was significantly different between in vivo-fertilized and IVF embryos at the 2-cell stage (Fig. 3A). The $\Delta \Psi_{\mathrm{m}}$ of 2 -cell stage of $<80 \%$ IVF embryos $(0.12 \pm 0.11, n=236 ; n$ indicates the number of blastomeres) was lower than that of in vivo-fertilized $(0.35 \pm 0.29, n=270)$ and of $\geq 80 \%$ IVF embryos $(0.23 \pm 0.15, n=228)$. The $\Delta \Psi_{\mathrm{m}}$ of in vivo-fertilized and IVF embryos was upregulated during development from the 1 - to the 2-cell stage (Fig. 3A; 1-cell stage in vivo-fertilized embryos: $0.21 \pm 0.14, n=106$; 1 -cell stage $\geq 80 \%$ IVF embryos: $0.05 \pm 0.04, n=26$; 1 -cell stage $<80 \%$ IVF embryos: $0.06 \pm 0.03, n=56$ ). There was no significant difference between the $\Delta \Psi_{\mathrm{m}}$ of the $\geq 80$ and $<80 \%$ IVF embryos at the 1-cell stage, but a significant difference was noticed at the 2-cell stage $(P<0.001$, Fig. 3A). These results indicated that the upregulation of $\Delta \Psi_{\mathrm{m}}$ between the 1- and 2-cell stage $<80 \%$ IVF embryos was lower than that of the others (Fig. 3A).

The ROS levels also indicated significant differences, as with the $\Delta \Psi_{\mathrm{m}}$, at the 2-cell stage (in vivo-fertilized embryos: $10.02 \pm 2.76 ; \geq 80 \%$ IVF group: $8.67 \pm 2.11 ;<80 \%$ IVF group: $7.79 \pm 2.58 ; P<0.001$, Fig. $3 \mathrm{~B})$. However, no significant difference was noticed in the $\Delta \Psi_{\mathrm{m}}$ and ROS at the 1 -cell stage between the $\geq 80 \%$ IVF and the $<80 \%$ IVF embryos (in vivo-fertilized embryos: $11.02 \pm 2.88 ; \geq 80 \%$ IVF embryos: $9.02 \pm 1.75$; <80\% IVF embryos: $9.63 \pm$ 1.96; Fig. 3B). Compared with the 1-cell stage embryos, ROS was significantly decreased in the 2-cell stage of $<80 \%$ IVF embryos ( $P<0.001$, Fig. 3B), but the ROS levels in the $\geq 80 \%$ IVF embryos were not significantly changed between the 1- and 2-cell stage (Fig. 3B).

In order to evaluate the ROS effects, lipid peroxidation-derived protein modification was measured with an linoleamid alkyne (LAA) detection kit. These results indicated that lipid peroxidation-derived protein modification did not correlate with ROS levels in 2-cell stage embryos (in vivo-fertilized embryos: $4.97 \pm 1.70$; $\geq 80 \%$ IVF embryos: $5.04 \pm 0.07 ;<80 \%$ IVF embryos: $5.86 \pm 2.05$; Fig. 4). The ROS levels of the 2-cell stage in vivo-fertilized embryos were higher than those of IVF embryos; however, the lipid peroxidation-derived protein modification of 2-cell stage in vivo-fertilized embryos was lower than that of IVF embryos (Fig. 4E). The ROS levels of 2 -cell stage $<80 \%$ IVF embryos were lower than those of the others; however, the protein modification levels of $<80 \%$ IVF embryos were higher than those of the others (Figs $3 \mathrm{~B}$ and $4 \mathrm{E}$ ). In some blastomeres of the $<80 \%$ IVF embryos, strong signals were observed in the cytoplasm or cell membrane (Fig. 4A, B, C, and D). These results indicated that the oxidative damage was more severe in $<80 \%$ IVF 2 -cell stage embryos than in the others. 
A
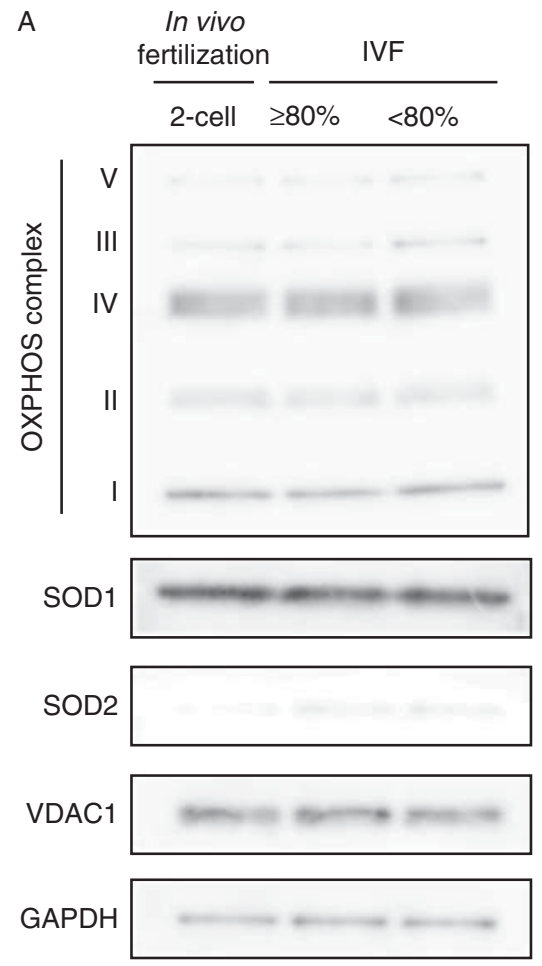

$\alpha$-tubulin $=-\infty$
B

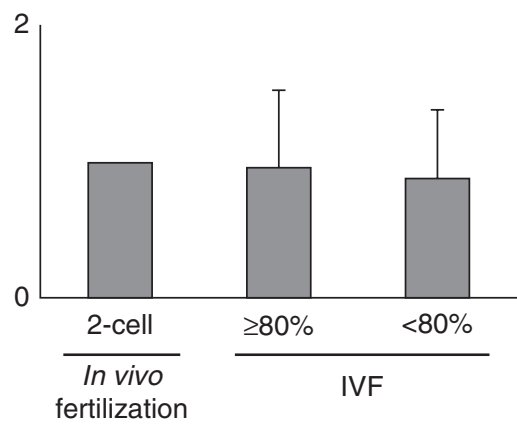

D

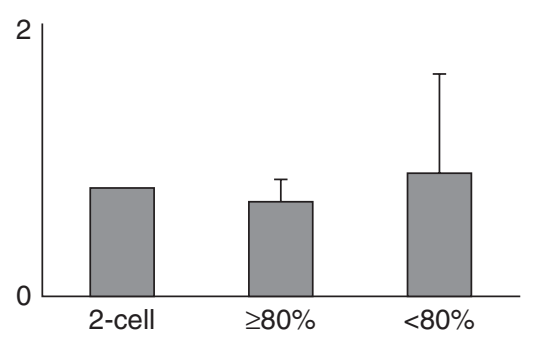

C

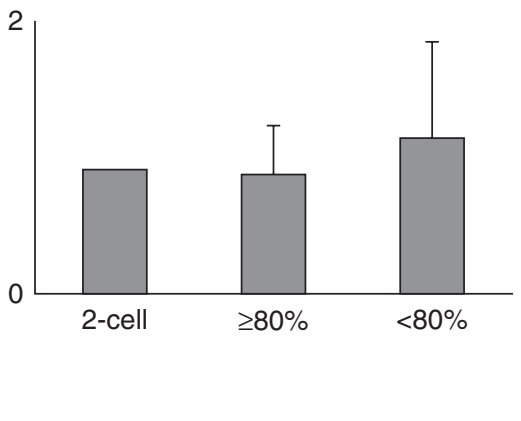

E

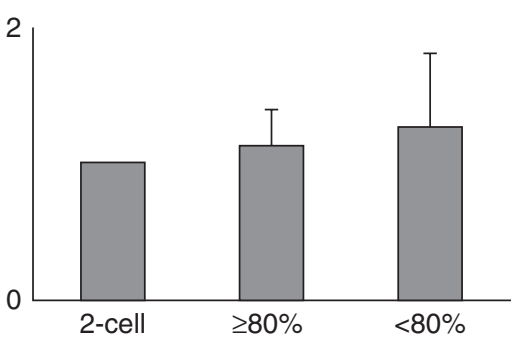

Figure 5 The expression of the oxidative phosphorylation (OXPHOS) complexes, superoxide dismutase 1 (SOD1), SOD2, and voltage-dependent anion channel 1 (VDAC1) in 2-cell stage embryos. The expression of OXPHOS complexes I-V, SOD1, SOD2, VDAC1, glyceraldehyde-3-phosphate dehydrogenase (GAPDH), and $\alpha$-tubulin in the 2-cell stage embryos was evaluated. The lysate that was obtained from 100 embryos was divided into two samples; one sample was used to detect the OXPHOS complexes and $\alpha$-tubulin; the other sample was used to detect SOD1, SOD2, VDAC1, and GAPDH (A). The concentrations of each of complex I (B), complex III (C), SOD1 (D), and VDAC1 (E) were quantified and indicated as arbitrary units relative to a set value of 1 for the samples from the 2 -cell stage in vivo-fertilized embryos (mean \pm s.D.). In this quantification, $\alpha$-tubulin was used as an internal standard because the GAPDH and $\alpha$-tubulin expression levels were almost the same.

\section{The expression of the five complexes of the OXPHOS system and SOD}

In order to confirm whether low $\Delta \Psi_{\mathrm{m}}$ was induced by the deletion of the five complexes of the OXPHOS system, the levels of expression of five complexes in the 2 -cell stage in vivo-fertilized, $\geq 80 \%$ IVF, and $<80 \%$ IVF embryos were compared. No significant differences were noted in the expression of the five complexes among the each groups (Fig. 5A, B, and C). VDAC1, which localizes to the outer mitochondrial membrane and allows for the diffusion of small hydrophilic molecules, was detected in order to compare the mitochondria number that was contained in embryos of each group. The VDAC1 expression levels were not significantly different, suggesting that the mitochondria number in each group was almost the same (Fig. 5A and $\mathrm{E}$ ). These results indicated that the differences in the $\Delta \Psi_{\mathrm{m}}$ were not dependent on the complexes of OXPHOS or the mitochondria number in the blastomeres.

Furthermore, in order to confirm whether the lipid peroxidation-derived protein modification in the 2-cell stage of $<80 \%$ IVF embryos was caused by a decrease in SOD, we evaluated the expression levels of SOD1 and SOD2 in each group (Fig. 5A). SOD1 expression levels were not significantly different between the $\geq 80$ and $<80 \%$ IVF embryos (Fig. 5C). Furthermore, SOD2 expression was detected; however, the levels were too low to compare (Fig. 5A). These results indicated that the lipid peroxidation-derived protein modification was not caused by SOD deletion in the $<80 \%$ IVF embryos.

\section{The production of ATP in IVF and IVF 2-cell stage embryos}

In order to compare the competence of ATP production between the 2-cell stage of in vivo-fertilized, $\geq 80 \%$ IVF, and $<80 \%$ IVF embryos, we measured the concentration of ATP in the lysates obtained from 20 to 50 embryos of each group, and calculated the concentration per one embryo. As a result, the concentration of ATP in in vivo-fertilized embryos was $1.66 \pm 0.19 \mathrm{pM} / \mathrm{embryo}$. The concentration of ATP in IVF embryos was lower than 


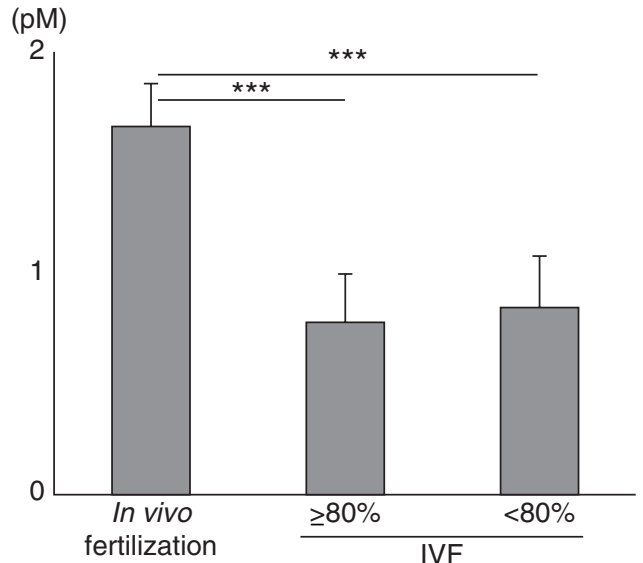

Figure 6 The concentration of ATP in 2-cell stage in vivo-fertilized and IVF embryos. The concentration of ATP in a 2-cell stage in vivofertilized and an IVF embryo was measured. As a result, the concentration of each embryo was: in vivo-fertilized embryo: $1.66 \pm$ $0.19 \mathrm{pM} /$ embryo, $\geq 80 \%$ IVF embryo: $0.78 \pm 0.22 \mathrm{pM} /$ embryo, $<80 \%$ IVF embryo: $0.85 \pm 0.23$ pM/embryo (mean \pm s.D.). ${ }^{* * *} P<0.001$.

in vivo-fertilized embryos at $\geq 80 \%$ IVF embryos: $0.78 \pm 0.22 \mathrm{pM} / \mathrm{embryo},<80 \%$ IVF embryos: $0.845 \pm$ $0.23 \mathrm{pM}$ /embryo (Fig. 6). No significant difference was observed between $\geq 80 \%$ and $<80 \%$ IVF embryos. When the $\Delta \Psi_{\mathrm{m}}$ is high, the production of ATP is active, whereas the production of ATP is decreased in mitochondria with low $\Delta \Psi_{\mathrm{m}}$. The concentration of ATP in 2-cell stage embryos of the $<80 \%$ IVF embryos was the same as that of the $\geq 80 \%$ IVF embryos even though the $\Delta \Psi_{\mathrm{m}}$ of the $<80 \%$ IVF embryos was lower than that of the $\geq 80 \%$ IVF embryos. These results indicated that the consumption of ATP in $<80 \%$ IVF embryos was lower than that of $\geq 80 \%$ IVF embryos at the 2-cell stage.

\section{Discussion}

For infertility treatment, the preimplantation development process is used as the criterion in the selection of blastocysts for implantation into the uterus. A recent study has reported that success in the progression of human embryos to blastocysts could be predicted with $>93 \%$ sensitivity before ZGA (Wong et al. 2010). In this study, the developmental process was captured and analyzed by noninvasive time-lapse imaging. The results indicated that the development of $47-67 \%$ of embryos was arrested and that almost all the embryos were arrested between the 2- and 8-cell stage. Furthermore, the time-lapse video was analyzed in order to identify the quantitative imaging parameters, and three parameters were identified that predicted blastocyst development success. These parameters depended on cytokinesis during the 1 - to 4 -cell stage. The cytokinesis gene expression levels of the arrested 2- and 4-cell embryos were lower than those of normal embryos (Wong et al. 2010). During this stage, ZGA is not initiated and maternal factors play critical roles in human embryo development (Braude et al. 1988, Dobson et al. 2004). These results suggested that the arrest of development correlated with oocyte quality. In addition, our results showed that the development of embryos with low $\Delta \Psi_{\mathrm{m}}$ tended to be arrested between the 2- and 4-cell stage (56/77, Table 2). This result was similar to those of noninvasive imaging study of human

Table 1 Blastocyst formation rate, the mitochondrial membrane potential $\left(\Delta \Psi_{m}\right)$ intensity, and reactive oxygen species (ROS) in the 2-cell stage IVF embryos.

\begin{tabular}{lcrrr}
\hline Female no. & $\begin{array}{c}\text { Total number of embryos } \\
\text { (culture/fluorescence probes) }\end{array}$ & Blastocyst $(\%)$ & JC-1 $(590 / 529 \mathrm{~nm})$ & \multicolumn{1}{c}{ ROS } \\
\hline 1 & $30(20 / 10)$ & $100(20 / 20)$ & $0.17 \pm 0.05$ & $8.86 \pm 0.88$ \\
2 & $14(10 / 4)$ & $100(10 / 10)$ & $0.26 \pm 0.06$ & $10.48 \pm 1.02$ \\
3 & $45(30 / 15)$ & $100(30 / 30)$ & $0.16 \pm 0.06$ & $9.68 \pm 1.42$ \\
4 & $45(30 / 15)$ & $96.7(29 / 30)$ & $0.21 \pm 0.07$ & $6.91 \pm 0.77$ \\
5 & $30(20 / 10)$ & $95(19 / 20)$ & $0.55 \pm 0.16$ & $9.85 \pm 1.25$ \\
6 & $43(30 / 13)$ & $93.3(28 / 30)$ & $0.34 \pm 0.12$ & $10.79 \pm 1.12$ \\
7 & $18(10 / 8)$ & $90(9 / 10)$ & $0.29 \pm 0.08$ & $11.51 \pm 1.37$ \\
8 & $28(18 / 10)$ & $88.9(16 / 18)$ & $0.24 \pm 0.36$ & $7.92 \pm 0.85$ \\
9 & $44(30 / 14)$ & $86.7(26 / 30)$ & $0.12 \pm 0.09$ & $6.42 \pm 0.88$ \\
10 & $31(20 / 11)$ & $85(17 / 20)$ & $0.09 \pm 0.04$ & $6.34 \pm 1.09$ \\
11 & $28(18 / 10)$ & $77.8(14 / 18)$ & $0.06 \pm 0.04$ & $3.50 \pm 0.65$ \\
12 & $29(20 / 9)$ & $70(14 / 20)$ & $0.10 \pm 0.04$ & $5.68 \pm 0.58$ \\
13 & $29(15 / 14)$ & $66.7(10 / 15)$ & $0.04 \pm 0.02$ & $7.40 \pm 0.71$ \\
14 & $24(15 / 9)$ & $56.7(17 / 15)$ & $0.38 \pm 0.13$ & $10.28 \pm 1.25$ \\
15 & $43(30 / 13)$ & $48.6(17 / 35)$ & $0.09 \pm 0.03$ & $4.69 \pm 0.73$ \\
16 & $50(35 / 15)$ & $45(9 / 20)$ & $0.19 \pm 0.07$ & $11.35 \pm 1.69$ \\
17 & $29(20 / 9)$ & $25(5 / 20)$ & $0.19 \pm 0.07$ & $7.49 \pm 0.91$ \\
18 & $40(20 / 20)$ & $23.3(7 / 30)$ & $0.20 \pm 0.07$ & $10.01 \pm 1.44$ \\
19 & $38(30 / 8)$ & $10(3 / 30)$ & $0.03 \pm 0.01$ & $8.56 \pm 0.87$ \\
20 & $42(30 / 12)$ & $0.07 \pm 0.03$ & $7.36 \pm 1.12$ \\
\hline
\end{tabular}

The embryos that were derived from oocytes, which were ovulated from one female by hormonal stimulation, were divided into two groups: one group was cultured for 5 days and the other group was stained with fluorescence probes. The female number indicates the number of the female mouse that was treated with hormonal stimulation for superovulation. 
Table 2 The stage at which the cell cleavage of IVF embryos was arrested.

\begin{tabular}{lcccc}
\hline Female & $\begin{array}{c}\text { Total number of } \\
\text { embryos in which } \\
\text { the cell cleavage } \\
\text { was arrested }\end{array}$ & $\begin{array}{c}\text { 2-cell } \\
\text { stage }\end{array}$ & $\begin{array}{c}\text { 4-cell } \\
\text { stage }\end{array}$ & $\begin{array}{c}>\text { 4-cell } \\
\text { stage }\end{array}$ \\
no. & 5 & & 2 & 3 \\
13 & 5 & & & 5 \\
14 & 18 & & 12 & 6 \\
16 & 11 & 3 & 10 & 1 \\
17 & 15 & 1 & 8 & 4 \\
18 & 23 & 4 & 20 & 2 \\
19 & 77 & 52 & 21 \\
Total & 5 & & & \\
\hline
\end{tabular}

Depending upon the type of cell cleavage arrest, the embryos were divided into the following three groups: 2-cell stage, 4-cell stage, and $>4$-cell stage. The development of these embryos was observed by time-lapse imaging. The female number in Table 2 corresponds to the number in Table 1.

embryos (Wong et al. 2010). Human embryos, which were used in the noninvasive imaging study, were generated by IVF, and oocytes were obtained according to the long lupron protocol (Wong et al. 2010). Therefore, these findings suggested that some human and mouse embryos that have been treated with the hormone for superovulation do not contain the proper maternal factors that are indispensable for early preimplantation embryos.

In our study, $<80 \%$ IVF embryos exhibited a low $\Delta \Psi_{\mathrm{m}}$, but the expression levels of complex I and III were the same as those of the others (Fig. 5B and C). Therefore, the expression of complexes in the OXPHOS system did not affect the $\Delta \Psi_{\mathrm{m}}$ level. The demand for ATP in the cell was also a factor in the regulation of $\Delta \Psi_{\mathrm{m}}$. Because $\Delta \Psi_{\mathrm{m}}$ is downregulated when the requirements for ATP decrease, we measured the concentration of ATP in the 2-cell stage embryos. Our results indicated that the concentration of ATP in $<80 \%$ IVF embryos was similar to that in $\geq 80 \%$ IVF embryos (Fig. 6), suggesting the following two possibilities: first, that the regulators other than OXPHOS complexes were lacking in mitochondria in the $<80 \%$ IVF embryos, so that the $\Delta \Psi_{\mathrm{m}}$ was not upregulated after the 1-cell stage or, secondly, that the $\Delta \Psi_{\mathrm{m}}$ was downregulated because the levels of some maternal factors that were essential for development were deficient in the $<80 \%$ IVF embryos and that the development of the embryos was prevented.

We then analyzed the ROS production in each embryo group. High ROS levels affect the development of preimplantation embryos (Takahashi 2012), but the ROS levels of the $<80 \%$ IVF embryos were lower than that of the other groups (Fig. 3B). When the electron transport chain (ETC) is inhibited or the requirement for ATP decreases, the $\Delta \Psi_{\mathrm{m}}$ is downregulated and the electrons accumulate in an early step of the ETC, complex I, or CoQ. In this situation, they can preferentially transport the electrons to $\mathrm{O}_{2}$ and produce $\mathrm{O}_{2}^{-}$, which is then released into the matrix. When the $\Delta \Psi_{\mathrm{m}}$ is high, the electrons are transported forward in the ETC, complex I releases little $\mathrm{O}_{2}^{-}$, and complex III mainly releases $\mathrm{O}_{2}^{-}$into the intermembrane space (Brand 2010). $\mathrm{O}_{2}^{-}$is converted to hydrogen peroxide $\left(\mathrm{H}_{2} \mathrm{O}_{2}\right)$ by SOD1 in the intermembrane space and by SOD2 in the matrix (Wallace \& Fan 2010). SOD1 in the 2-cell stage IVF embryos was expressed at the same levels in each group. However, SOD2 was expressed at low levels (Fig. 5A), and there were no apparent differences between the groups. In mitochondria with high $\Delta \Psi_{\mathrm{m}}, \mathrm{O}_{2}^{-}$was converted into $\mathrm{H}_{2} \mathrm{O}_{2}$, which diffuses into the cytoplasm from mitochondria; hence, low ROS levels were observed in mitochondria with high $\Delta \Psi_{\mathrm{m}}$ (Fig. 2L). However, high ROS levels were localized in the mitochondria with low $\Delta \Psi_{\mathrm{m}}$ (Fig. $2 \mathrm{H}$ ). It was considered that the $\mathrm{O}_{2}^{-}$that was released from complex I accumulated in the matrix because $\mathrm{O}_{2}^{-}$is highly membrane impermeable (Muller et al. 2004), and ROS signals accumulated in the mitochondrial matrix of low $\Delta \Psi_{\mathrm{m}}<80 \%$ IVF embryos (Fig. 2I, J, and K). The lipid peroxidation-derived protein modification levels were higher in the $<80 \%$ IVF embryos than in the other groups (Fig. 4). $\mathrm{O}_{2}^{-}$is a stronger oxidant than $\mathrm{H}_{2} \mathrm{O}_{2}$ (Maron \& Michel 2012). The ROS concentrations in the blastomeres of the $<80 \%$ IVFembryos were lower than those of the others, but oxidative stress in the mitochondria may have been higher than those of the others. It was also considered that ROS localization differed between mitochondria with high and low $\Delta \Psi_{\mathrm{m}}$ and this may be important for the early development of embryos because recent reports have indicated that ROS plays crucial roles in various physiological processes (Alfadda \& Sallam 2012).

Although the $\Delta \Psi_{\mathrm{m}}$ and ROS of the 2-cell stage in vivofertilized embryos were higher than those of the other groups, all embryos developed to blastocysts (Fig. 3). The oviduct plays an important role in gamete maturation, gamete transportation, fertilization, and preimplantation development (Ellington 1991, Barriere et al. 2002, Lyons et al. 2006, Brussow et al. 2008, Kolle et al. 2010, Gad et al. 2011). Therefore, some factors in the oviduct may activate embryonic mitochondria and protect them from oxidative stress (Figs 3 and 5).

The mechanism behind the control of the $\Delta \Psi_{\mathrm{m}}$ in the 2-cell stage embryos is unclear, but superovulation induces the ovulation of oocytes that are not ovulated in normal ovulation. Oocytes that are normally regressed or are still too immature to ovulate are forcibly ovulated by hormonal stimulation. These oocytes do not contain the proper maternal factors, $\mathrm{mRNA}$, proteins, and mature mitochondria (Krisher 2004, Thouas et al. 2004, Cui \& Kim 2007, Hamatani et al. 2008, Mtango et al. 2008, Mundim et al. 2009, Wai et al. 2010, Eichenlaub-Ritter et al. 2011). Therefore, we considered that some IVF embryos that are derived from superovulated oocytes may contain mitochondrial functional defects or not enough maternal factors to upregulate the $\Delta \Psi_{\mathrm{m}}$. Furthermore, it was considered that the decrease in demand for ATP suppressed the upregulation of $\Delta \Psi_{\mathrm{m}}$ 
after the 1-cell stage; as a result, $\mathrm{O}_{2}^{--}$released from complex $\mathrm{I}$ accumulated in the matrix and the mitochondria were damaged by the oxidative stress.

Our results showed that the upregulation of $\Delta \Psi_{\mathrm{m}}$ after the 1-cell stage was significant for the success of preimplantation development; however, superovulated oocytes that were induced by hormonal stimulation contained a number of low-quality oocytes, and the embryos that were derived from these oocytes had defects in controlling $\Delta \Psi_{\mathrm{m}}$ during early preimplantation development. Therefore, these embryos were easily damaged by the oxidative stress because ROS accumulated in low $\Delta \Psi_{\mathrm{m}}$ mitochondria in 2-cell stage embryos and the development of damaged embryos tended to be arrested from the 2- to 4-cell stage.

\section{Declaration of interest}

The authors declare that there is no conflict of interest that could be perceived as prejudicing the impartiality of the research reported.

\section{Funding}

This research did not receive any specific grant from any funding agency in the public, commercial or not-for-profit sector.

\section{Acknowledgements}

The authors thank Enago (www.enago.jp) for the English language review.

\section{References}

Alfadda AA \& Sallam RM 2012 Reactive oxygen species in health and disease. Journal of Biomedicine \& Biotechnology 2012936486. (doi:10.1155/2012/936486)

Barriere P, Thibault E \& Jean M 2002 Role of Fallopian tube in fertilization. La Revue du Praticien 52 1757-1761.

Brand MD 2010 The sites and topology of mitochondrial superoxide production. Experimental Gerontology 45 466-472. (doi:10.1016/j. exger.2010.01.003)

Braude P, Bolton V \& Moore S 1988 Human gene expression first occurs between the four- and eight-cell stages of preimplantation development. Nature 332 459-461. (doi:10.1038/332459a0)

Brussow KP, Ratky J \& Rodriguez-Martinez H 2008 Fertilization and early embryonic development in the porcine Fallopian tube. Reproduction in Domestic Animals 43 (Suppl 2) 245-251. (doi:10.1111/j.1439-0531. 2008.01169.x)

Combelles CM, Holick EA, Paolella LJ, Walker DC \& Wu Q 2010 Profiling of superoxide dismutase isoenzymes in compartments of the developing bovine antral follicles. Reproduction 139 871-881. (doi:10.1530/REP-09-0390)

Cui XS \& Kim NH 2007 Maternally derived transcripts: identification and characterisation during oocyte maturation and early cleavage. Reproduction, Fertility, and Development 19 25-34. (doi:10.1071/RD06128)

Dobson AT, Raja R, Abeyta MJ, Taylor T, Shen S, Haqq C \& Pera RA 2004 The unique transcriptome through day 3 of human preimplantation development. Human Molecular Genetics 13 1461-1470. (doi:10.1093/ hmg/ddh157)

Drago I, Pizzo P \& Pozzan T 2011 After half a century mitochondrial calcium in- and efflux machineries reveal themselves. EMBO Journal 30 4119-4125. (doi:10.1038/emboj.2011.337)
Eichenlaub-Ritter U, Wieczorek M, Luke S \& Seidel T 2011 Age related changes in mitochondrial function and new approaches to study redox regulation in mammalian oocytes in response to age or maturation conditions. Mitochondrion 11 783-796. (doi:10.1016/j.mito.2010.08.011)

Ellington JE 1991 The bovine oviduct and its role in reproduction: a review of the literature. Cornell Veterinarian 81 313-328.

Fattman CL, Schaefer LM \& Oury TD 2003 Extracellular superoxide dismutase in biology and medicine. Free Radical Biology \& Medicine 35 236-256. (doi:10.1016/S0891-5849(03)00275-2)

Gad A, Besenfelder U, Rings F, Ghanem N, Salilew-Wondim D, Hossain MM, Tesfaye D, Lonergan P, Becker A, Cinar U et al. 2011 Effect of reproductive tract environment following controlled ovarian hyperstimulation treatment on embryo development and global transcriptome profile of blastocysts: implications for animal breeding and human assisted reproduction. Human Reproduction 26 1693-1707. (doi:10.1093/humrep/der110)

Gyllensten U, Wharton D, Josefsson A \& Wilson AC 1991 Paternal inheritance of mitochondrial DNA in mice. Nature 352 255-257. (doi:10.1038/352255a0)

Hamatani T, Carter MG, Sharov AA \& Ko MS 2004 Dynamics of global gene expression changes during mouse preimplantation development. Developmental Cell 6 117-131. (doi:10.1016/S1534-5807(03)00373-3)

Hamatani T, Yamada M, Akutsu H, Kuji N, Mochimaru Y, Takano M, Toyoda M, Miyado K, Umezawa A \& Yoshimura Y 2008 What can we learn from gene expression profiling of mouse oocytes? Reproduction 135 581-592. (doi:10.1530/REP-07-0430)

Hirst J, Carroll J, Fearnley IM, Shannon RJ \& Walker JE 2003 The nuclear encoded subunits of complex I from bovine heart mitochondria. Biochimica et Biophysica Acta $\mathbf{1 6 0 4}$ 135-150. (doi:10.1016/ S0005-2728(03)00059-8)

Kimura N, Tsunoda S, luchi Y, Abe H, Totsukawa K \& Fujii J 2010 Intrinsic oxidative stress causes either 2-cell arrest or cell death depending on developmental stage of the embryos from SOD1-deficient mice. Molecular Human Reproduction 16 441-451. (doi:10.1093/molehr/gaq007)

Kolle S, Reese S \& Kummer W 2010 New aspects of gamete transport, fertilization, and embryonic development in the oviduct gained by means of live cell imaging. Theriogenology 73 786-795. (doi:10.1016/ j.theriogenology.2009.11.002)

Krisher RL 2004 The effect of oocyte quality on development. Journal of Animal Science 82 (E-Suppl) E14-E23.

Lacham-Kaplan O \& Trounson A 2008 Reduced developmental competence of immature, in-vitro matured and postovulatory aged mouse oocytes following IVF and ICSI. Reproductive Biology and Endocrinology 6 58. (doi:10.1186/1477-7827-6-58)

Lansman RA, Avise JC \& Huettel MD 1983 Critical experimental test of the possibility of "paternal leakage" of mitochondrial DNA. PNAS 80 1969-1971. (doi:10.1073/pnas.80.7.1969)

Lyons RA, Saridogan E \& Djahanbakhch O 2006 The reproductive significance of human Fallopian tube cilia. Human Reproduction Update 12 363-372. (doi:10.1093/humupd/dml012)

Mancini M, Anderson BO, Caldwell E, Sedghinasab M, Paty PB \& Hockenbery DM 1997 Mitochondrial proliferation and paradoxical membrane depolarization during terminal differentiation and apoptosis in a human colon carcinoma cell line. Journal of Cell Biology 138 449-469. (doi:10.1083/jcb.138.2.449)

Maron BA \& Michel T 2012 Subcellular localization of oxidants and redox modulation of endothelial nitric oxide synthase. Circulation Journal $\mathbf{7 6}$ 2497-2512. (doi:10.1253/circj.CJ-12-1207)

Mermillod P, Dalbies-Tran R, Uzbekova S, Thelie A, Traverso JM, Perreau C, Papillier P \& Monget P 2008 Factors affecting oocyte quality: who is driving the follicle? Reproduction in Domestic Animals 43 (Suppl 2) 393-400. (doi:10.1111/j.1439-0531.2008.01190.x)

Motta PM, Nottola SA, Makabe S \& Heyn R 2000 Mitochondrial morphology in human fetal and adult female germ cells. Human Reproduction 15 (Suppl 2) 129-147. (doi:10.1093/humrep/15.suppl_2.129)

Mtango NR, Potireddy S \& Latham KE 2008 Oocyte quality and maternal control of development. International Review of Cell and Molecular Biology 268 223-290. (doi:10.1016/S1937-6448(08)00807-1)

Muller FL, Liu Y \& Van Remmen H 2004 Complex III releases superoxide to both sides of the inner mitochondrial membrane. Journal of Biological Chemistry 279 49064-49073. (doi:10.1074/jbc.M407715200) 
Mundim TC, Ramos AF, Sartori R, Dode MA, Melo EO, Gomes LF, Rumpf R \& Franco MM 2009 Changes in gene expression profiles of bovine embryos produced in vitro, by natural ovulation, or hormonal superstimulation. Genetics and Molecular Research 8 1398-1407. (doi:10. 4238/vol8-4gmr646)

Piko L \& Taylor KD 1987 Amounts of mitochondrial DNA and abundance of some mitochondrial gene transcripts in early mouse embryos. Developmental Biology 123 364-374. (doi:10.1016/0012-1606(87)90395-2)

Reynier P, May-Panloup P, Chretien MF, Morgan CJ, Jean M, Savagner F, Barriere P \& Malthiery Y 2001 Mitochondrial DNA content affects the fertilizability of human oocytes. Molecular Human Reproduction 7 425-429. (doi:10.1093/molehr/7.5.425)

Sato M \& Sato K 2011 Degradation of paternal mitochondria by fertilization-triggered autophagy in C. elegans embryos. Science 334 1141-1144. (doi:10.1126/science.1210333)

Sazanov LA 2007 Respiratory complex I: mechanistic and structural insights provided by the crystal structure of the hydrophilic domain. Biochemistry 46 2275-2288. (doi:10.1021/bi602508x)

Smiley ST, Reers M, Mottola-Hartshorn C, Lin M, Chen A, Smith TW, Steele GD Jr \& Chen LB 1991 Intracellular heterogeneity in mitochondrial membrane potentials revealed by a J-aggregate-forming lipophilic cation JC-1. PNAS 88 3671-3675. (doi:10.1073/pnas.88.9.3671)

St-Pierre J, Buckingham JA, Roebuck SJ \& Brand MD 2002 Topology of superoxide production from different sites in the mitochondrial electron transport chain. Journal of Biological Chemistry 277 44784-44790. (doi:10.1074/jbc.M207217200)

Sutovsky P, Moreno RD, Ramalho-Santos J, Dominko T, Simerly C \& Schatten G 1999 Ubiquitin tag for sperm mitochondria. Nature 402 371-372. (doi:10.1038/46466)

Sutovsky P, Moreno RD, Ramalho-Santos J, Dominko T, Simerly C \& Schatten G 2000 Ubiquitinated sperm mitochondria, selective proteolysis, and the regulation of mitochondrial inheritance in mammalian embryos. Biology of Reproduction 63 582-590. (doi:10.1095/biolreprod63.2.582)

Tadros W \& Lipshitz HD 2009 The maternal-to-zygotic transition: a play in two acts. Development 136 3033-3042. (doi:10.1242/dev.033183)

Takahashi M 2012 Oxidative stress and redox regulation on in vitro development of mammalian embryos. Journal of Reproduction and Development 58 1-9. (doi:10.1262/jrd.11-138N)

Thouas GA, Trounson AO, Wolvetang EJ \& Jones GM 2004 Mitochondrial dysfunction in mouse oocytes results in preimplantation embryo arrest in vitro. Biology of Reproduction 71 1936-1942. (doi:10.1095/biolreprod. 104.033589)

Tsukamoto S, Kuma A, Murakami M, Kishi C, Yamamoto A \& Mizushima N 2008 Autophagy is essential for preimplantation development of mouse embryos. Science 321 117-120. (doi:10.1126/science.1154822)
Turrens JF 2003 Mitochondrial formation of reactive oxygen species. Journal of Physiology 552 335-344. (doi:10.1113/jphysiol.2003. 049478)

Van Blerkom J \& Davis P 2006 High-polarized $\left(\Delta \Psi_{\mathrm{m}}(\mathrm{HIGH})\right)$ mitochondria are spatially polarized in human oocytes and early embryos in stable subplasmalemmal domains: developmental significance and the concept of vanguard mitochondria. Reproductive BioMedicine Online 13 246-254. (doi:10.1016/S14726483(10)60622-0)

Van Blerkom J, Davis P, Mathwig V \& Alexander S 2002 Domains of highpolarized and low-polarized mitochondria may occur in mouse and human oocytes and early embryos. Human Reproduction 17 393-406. (doi:10.1093/humrep/17.2.393)

Wadia JS, Chalmers-Redman RM, Ju WJ, Carlile GW, Phillips JL, Fraser AD \& Tatton WG 1998 Mitochondrial membrane potential and nuclear changes in apoptosis caused by serum and nerve growth factor withdrawal: time course and modification by (-)-deprenyl. Journal of Neuroscience 18 932-947.

Wai T, Teoli D \& Shoubridge EA 2008 The mitochondrial DNA genetic bottleneck results from replication of a subpopulation of genomes. Nature Genetics 40 1484-1488. (doi:10.1038/ng.258)

Wai T, Ao A, Zhang X, Cyr D, Dufort D \& Shoubridge EA 2010 The role of mitochondrial DNA copy number in mammalian fertility. Biology of Reproduction 83 52-62. (doi:10.1095/biolreprod.109.080887)

Wallace DC \& Fan W 2010 Energetics, epigenetics, mitochondrial genetics. Mitochondrion 10 12-31. (doi:10.1016/j.mito.2009.09.006)

Wilding M, Dale B, Marino $M$, di Matteo L, Alviggi C, Pisaturo ML, Lombardi L \& De Placido G 2001 Mitochondrial aggregation patterns and activity in human oocytes and preimplantation embryos. Human Reproduction 16 909-917. (doi:10.1093/humrep/16.5.909)

Wilding M, Coppola G, Dale B \& Di Matteo L 2009 Mitochondria and human preimplantation embryo development. Reproduction 137 619-624. (doi:10.1530/REP-08-0444)

Wong CC, Loewke KE, Bossert NL, Behr B, De Jonge CJ, Baer TM \& Reijo Pera RA 2010 Non-invasive imaging of human embryos before embryonic genome activation predicts development to the blastocyst stage. Nature Biotechnology 28 1115-1121. (doi:10.1038/nbt.1686)

Received 5 July 2013

First decision 30 July 2013

Revised manuscript received 28 November 2013

Accepted 23 January 2014 